\title{
QUEEN'S
UNIVERSITY
BELFAST
}

\section{Ireland's conundrum on union bargaining rights: assessing the Industrial Relations Amendment Act 2015}

Dobbins, T., Cullinane, N., \& Sheehan, B. (2020). Ireland's conundrum on union bargaining rights: assessing the Industrial Relations Amendment Act 2015. Industrial Relations Journal, 51(1-2), 75-91.

https://doi.org/10.1111/irj.12281

Published in:

Industrial Relations Journal

Document Version:

Peer reviewed version

Queen's University Belfast - Research Portal:

Link to publication record in Queen's University Belfast Research Portal

Publisher rights

(C) 2020 Brian Towers (BRITOW) and John Wiley \& Sons Ltd. This work is made available online in accordance with the publisher's policies. Please refer to any applicable terms of use of the publisher.

\section{General rights}

Copyright for the publications made accessible via the Queen's University Belfast Research Portal is retained by the author(s) and / or other copyright owners and it is a condition of accessing these publications that users recognise and abide by the legal requirements associated with these rights.

Take down policy

The Research Portal is Queen's institutional repository that provides access to Queen's research output. Every effort has been made to ensure that content in the Research Portal does not infringe any person's rights, or applicable UK laws. If you discover content in the Research Portal that you believe breaches copyright or violates any law, please contact openaccess@qub.ac.uk. 
Ireland's conundrum on union bargaining rights: assessing the Industrial Relations Amendment Act 2015

\begin{abstract}
Anglophone countries address the question of workplace-level union bargaining rights via the mechanism of statutory recognition. Existing literature has evaluated such regimes as underpinned by several weaknesses. In contrast, Ireland presents an unusual case whereby the question of bargaining rights is resolved via collective dispute resolution procedures combining voluntary and statutory provisions. However, employer challenges and civil court rulings resulted in the weakening of these procedures from a trade union perspective. We assess the latest attempts to reform the Irish provisions via the Industrial Relations (Amendment) Act 2015, evaluating the implications for unions and their capacity to represent members' on pay and working conditions in comparison to Anglophone statutory recognition regimes.
\end{abstract}




\section{INTRODUCTION}

This article assesses the impact of Ireland's revised Industrial Relations (Amendment) Act 2015 for resolving disputes involving union members in firms where collective bargaining is not practised. The contribution of the article lies in its comparative evaluation of what amounts to a highly experimental approach to providing workers in non-union firms with collective bargaining rights in comparison to those well-known statutory regimes of union recognition predominating in the Anglophone sphere. Given the relative inability of the latter regimes to counter problems of a growing representation gap in union coverage, we consider how the Irish regime compares in delivering effective union voice for members in non-union workplaces. The value of the article is that it is the first research to analyse the industrial relations implications of IRAA 2015 for Irish trade unions, which showcases new primary empirical evidence regarding the experiences of union officials.

Ireland remains unique among so-called ‘Anglophone' countries in not legislating for statutory union recognition for collective bargaining purposes. There is a legal assumption that the Constitution of Ireland (1937) contains a double-edged sword: while guaranteeing citizens' rights to form associations and trade unions, paradoxically, the Irish courts interpret this as not imposing obligations on employers to recognise such bodies (Hogan and White, 2003: 1793). The historical approach in Ireland has been to pursue recognition through voluntary industrial relations means. Under the Industrial Relations Act 1969, unions were able to forward claims for union recognition to the Labour Court: however, the status of any Court ruling was purely a voluntary recommendation with no legal force. This voluntary route has proved problematic for unions as collective bargaining coverage and union membership density have diminished, notably in the private sector. Walsh (2018) notes that union density declined from $36 \%$ of employees in 2003 to $25 \%$ in 2017. In the private sector, density has declined from $27 \%$ to 14\%. Labour and product market changes, alongside a hardening in employers' preferences for non-unionism, weaken unions’ ability to establish workplace presence (Cullinane and Dundon, 2012; Turner et al., 2013; Sheehan, 2008).

A Government commission appointed to review the matter in the late 1990s under the Irish social partnership model recommended a policy solution to the vexed matter of recognition. In recommending against statutory recognition, the commission identified not merely the constitutional impediment above, but championed the existing voluntarist IR system as a crucial component of Ireland's political economy. There were fears that to break from 
voluntarism would jeopardise the country's attractiveness to the mostly non-union US multinationals who had established plants in Ireland (Gunnigle et al., 2009). Instead, the commission recommended dispute resolution procedures for addressing collective disputes in firms where collective bargaining was absent. These became encapsulated in the Industrial Relations Amendment Act 2001 and subsequent 2004 Miscellaneous Provisions amendment (henceforth, IRAA 2001-2004). In firms where collective bargaining is absent, the legislation provided that unionised workers can refer unresolved local disputes on pay and conditions to external third-party state institutions for rulings on those matters (but not union recognition, which is proscribed). While union uptake of this legislation was reasonably high in the 2000s, it was subject to a successful Ryanair challenge in 2007 at the Supreme Court (Doherty, 2013; O’Sullivan and Gunnigle, 2009). The consequences of that ruling introduced greater legal complexity into the procedures, much to the chagrin of unions. Unions stopped using the legislation after 2007.

It was not until the middle part of this decade that the fallout from the Supreme Court ruling was addressed by public policy, resulting in the Industrial Relations (Amendment) Act of 2015. The review process underpinning this resulted in several significant procedural reforms. The IRAA 2015 is unexamined in the IR literature, hence the contribution of this article. The article is structured as follows. Section 2 briefly reviews recurring thematic issues in Anglophone countries regarding regulatory issues in designing collective bargaining rights procedures. Section 3 summarises the original Irish IRAA 2001-04 and the problems it subsequently encountered, necessitating review and reform. Section 4 describes the methods and evidence sources used to evaluate the reformed legislation. Section 5 evaluates the IRAA 2015, and section 6 considers subsequent Labour Court cases and union evaluations. Section 7 looks at alternative strategies unions are considering, followed by the discussion and conclusion in the final section.

\section{COMPARATIVE ANGLOPHONE BARGAINING RIGHTS}

Compared to many continental western European countries (especially the Nordic countries), Anglophone countries like Ireland and the UK have historically had fewer institutional measures to extend collective bargaining coverage beyond workplace level; meaning that collective bargaining coverage is lower, thus limiting the wider reach of union influence (Ibsen and Tapia, 2017). Before detailing Irish practice, it is helpful to set the study within the broader Anglophone context of collective bargaining rights, which, like Ireland, are decentralised 
industrial relations systems known to utilise some form of statutory representation rights. Variation exists across the Anglophone sphere nonetheless: some are highly legalised certification regimes (Godard, 2003), while others encourage voluntarism under the shadow of the law (Forsyth et al., 2017; Wood and Godard, 1999). However, commonality exists on procedures, like: criteria for trade union representativeness in becoming a certified agent for bargaining; timelines involved in the procedural application to secure bargaining rights; and protections from employer interference/unfair labour practices (Bogg, 2012; Doherty, 2013; Ewing and Hendy, 2017; Forsyth et al., 2017; Gall, 2010; Godard, 2003; Harcourt et al., 2019).

Criteria exist across Anglophone jurisdictions regarding union membership thresholds, verified through either 'card check' or workplace ballots. Expectations of majoritarian consent dominate union representativeness thresholds (Bogg, 2012; Doherty, 2013; Forsyth et al., 2017; Harcourt et al., 2019). Critics note majoritarian membership criteria work well where union presence is strong but are ill-suited for weakly organised workplaces. Card checks or employee petitions may offer more favourable outcomes to unions than ballots (Forsyth et al., 2017; Walpole, 2015).

Given such systems are characterised by voluntary initiation by unions via statutory procedure, timeline duration is a well-noted concern: chiefly time from initial application to formal recognition, and time from recognition to concluding first agreement. Lengthy procedural timelines are unhelpful for unions facing anti-union or 'union reluctant' employers; for example, employees are more exposed to employer pressure and the natural momentum of organising declines (Holgate et al. 2018). For example, that the United States exemplifies lengthy procedures with no time restrictions, and provides ample scope for employers' right to appeal, is widely perceived as a significant limitation of the certification process in this country (Godard, 2003; Wood and Godard 1999).

One assumption underpinning procedural design for union bargaining rights is preventing illegitimate employer interference. This assumption is exemplified in the variable protections against employer interference and bad faith bargaining among Anglophone countries, ranging from specific unfair labour practices to codes of good faith bargaining (Barry and Walsh, 2007; Bogg and Novitz, 2018; Forsyth et al., 2017). Where an employer violates such provisions, unions can often seek condensed procedural timelines and automatic certification. In some Anglophone jurisdictions, a right to reasonable union access to the workforce complements 
protections against employer obstructionism. Nevertheless, coverage and scope of such provisions is often incomplete due to local level power imbalances between employers and individual workers in non-union contexts (Bogg, 2012; Gall, 2012).

In summary, Anglophone statutory union recognition regimes provide different procedural supports which, in practice, possess variable and incomplete reach as protective mechanisms for enabling recognition. Such porosity in institutional design provides several opportunities for employer manipulation and suppression; a particular difficulty as much of the 'heavy lifting' for procedural completion relies on voluntary activities of workers at local-level. Thus, in the next section, we review the Irish procedures which, although possessing the same objective of enabling union representation rights, do so via a rather distinct regulatory route.

\section{IRELAND’S ‘RIGHT TO BARGAIN’ PROCEDURES}

The Irish procedures differ from international norms in not providing a statutory route for unions to become certified agents for collective bargaining. There is no legal right to direct negotiations between unions and employers in workplaces. Instead, the Irish procedures designed an indirect/shadow form of 'arms-length' collective bargaining; labelled as a 'right to bargain' (Geary and Gamwell, 2019). This involved third party state dispute resolution institutions comparing collective bargaining outcomes in unionised firms with those of union members in those workplaces in dispute, where employers refused to recognise unions for collective bargaining purposes. The procedures allowed unions to resolve disputes involving members in workplaces where collective bargaining was absent (see Cullinane and Dobbins, 2014; D'Art and Turner, 2011; Doherty, 2013; Gibbons, 2015). Unions could submit disputed items to the then Labour Relations Commission (LRC) for conciliation, and then, if unresolved, the Labour Court would issue recommendations on disputed pay and conditions. If still unresolved, unions could request a binding determination by the Labour Court, enforceable in the civil courts.

Unlike the Anglophone models discussed above, referred disputes did not require minimum thresholds of member support or ballots. Such practice was arguably a boon to unions, insofar as they could secure wins via the Labour Court to convince non-members of their efficacy. Indeed, this was an issue of contention for many employers dissatisfied at the ability of unions to subject them to claims with only minority membership in organisations. However, the procedure's timeline was protracted and debilitating for union organising. Initially, disputes in 
procedure could take as long as 18 months, curtailing local organising momentum (Gibbons, 2015; Murphy and Turner, 2014). Indeed, unions requested policymakers to shorten the initial timescales. Subsequently, the IRAA 2004 fast-tracked the process with a shorter six month timeframe. The streamlined timescales also enhanced procedural efficacy for unions; evidenced by an annual case increase from 26 (between 2001-2004) to 65 (2004-2007).

Provisions covering employer interference also emerged in the 2004 reform, with a new Code of Practice on Victimisation, arising from an employee's membership or non-membership of a union. However, these protections were weak and reflected the American system of providing for limitless employer challenge. For example, unions widely perceived employers to be deploying various stonewalling tactics to thwart cases. Such tactics were frequently alleged by union officials to include harassment of local activists, attempting to string out disputes through a combination of bad faith bargaining, challenging Court jurisdiction by claiming that union claims were erroneous, non-attendance at LRC and Court hearings and civil court referrals. This type of employer bad faith bargaining could become compounded over time as the legislation was confined to resolving episodic issues in dispute in individual firms. Sustained employer opposition to engaging the union locally could entail not engaging any further with unions once dispute items had gone through procedures. Unions were thus required to revisit the procedures for resolving further disputes arising, which itself proved demanding on union time and resources and dispute duration (see Gibbons, 2015).

These problems aside, unions were reasonably disposed to the procedures, as evidenced, in particular, by the significantly increased uptake after the 2004 amendment. Between 2002 and 2014, Ireland's Labour Court issued 109 recommendations (82 of which came during a three year' golden period' of 2004-2006), with an additional 28 binding determinations. Indigenous firms were most subject to Court rulings. About two-thirds of recommendations backed union claims, providing pay rises, better conditions, and improved grievance procedures. Recommendations often shadowed collective bargaining norms in unionised sectors, imposing similar outcomes on non-union firms (Cullinane and Dobbins, 2014). Thus, echoing Ewing's (2005) distinction, the procedures became more than a representational mechanism and quasiregulatory in colonising non-union zones with unionised norms. As the Labour Court observed, its role was: 
...to have particular regard to rates of pay and other conditions of employment established by collective bargaining in establishments providing a broadly similar level of service to customers. (LCR17760 Ashford Castle and SIPTU Union)

For a brief period under the 2004 revision, the Irish procedures contrasted quite favourably with statutory procedures elsewhere in the Anglosphere. Where not provided with statutory supports in signing a 'first agreement', statutory recognition in itself does not compel employer concessions in subsequent rounds of collective bargaining. The Irish procedures circumvented this by allowing unions to utilise Labour Court powers to raise standards by 'shadowing' collective bargaining norms in unionised comparators.

However, from a union standpoint, the procedures were rendered obsolete by the 2007 Supreme Court ruling. As Doherty (2013) observes, the Supreme Court judgment ruptured procedure usage. It ruled that the Labour Court in DECP051 Ryanair and IMPACT/Irish Airlines Pilot Association had insufficient evidence to justify a dispute existed, being over-reliant on union 'opinion' (for example, there was very little evidential base for determining trade union membership representativeness). The Supreme Court judged that the Labour Court needed to rely on an increased threshold of proof in assessing disputes, with a stronger evidential basis for making assessments regarding inter-employer comparability. The Labour Court had also erred in deciding the employer did not collectively bargain. The Supreme Court reasoned collective bargaining in non-unionised companies need not take a unionised form, provided it functions in a 'fair and reasonable' manner with 'a view to reaching agreement.' Employers could propose in-house, non-union employee representation bodies (NER) as legitimate collective bargaining, thereby potentially avoiding unions. Nor could employees reject these internal bodies without engaging them. The Labour Court also had not followed fair procedures in allowing membership non-disclosure.

In summary, the Irish procedures partially re-orientated the route to representation rights by circumventing thorny problems of recognition at local-level via the adoption of a regulatory mode of oversight through the Labour Court. The form of shadow collective bargaining that emerged largely compared unionised sectoral norms, de facto operating as a form of extension clause as seen in many European countries. Yet procedural usage was localised at firm-level and prone to the same employer hostility evident in other Anglophone spheres; culminating in employer recourse to the civil courts to challenge the procedures, and diminish their utility for unions. Indeed, following the Supreme Court judgment, only six cases went to the Labour 
Court between 2008 and 2014. Unions believed that employers would circumvent procedures with non-union bargaining agents and evidential thresholds were too onerous (especially exposing members to hostile employers when providing evidence). Moreover, the 2008 financial crisis, the breakdown of social partnership in 2009, and austerity, shifted industrial relations priorities elsewhere for government and a (public sector dominated) union movement (Doherty, 2011). Disillusioned, unions, through the Irish Congress of Trade Unions (ICTU), sought support from the International Labour Organisation to help advance the case for reforming existing provisions. The ILO subsequently advised the Irish government to revisit arrangements for collective bargaining. Momentum gathered in 2011 when unions' traditional ally the Labour Party became a partner in a Fine Gael-led coalition government. A governmentsponsored review ensued, resulting in procedural reforms contained in Part III of the IRAA 2015. The remainder of the article considers the impact of these reforms on unions utilising the procedures to secure bargaining rights.

\section{METHODS}

The research draws on several empirical data sources. Apart from examining the content of IRAA 2015 itself, the authors first examined documents obtained from a 2018 Freedom of Information (FOI) request to the relevant state department (Department of Business, Enterprise and Innovation) responsible for the review process. The objective of accessing these documents was to understand the deliberations during the review process between government, employer, and union representatives. This request returned 50 documents, including stakeholder position papers, minutes of meetings between stakeholders, and email correspondence. The main actors comprised Departmental civil servants, Ibec (Ireland's main employer confederation), the Irish Congress of Trade Unions (ICTU), and American Chamber of Commerce (AmCham) ${ }^{1}$. The

\footnotetext{
${ }^{1}$ Although not an officially recognised industrial relations social partner per se, AmCham Ireland was consistently involved in the review process. Successive Irish governments have prioritised foreign direct investment (FDI) from the United States, and representatives of these interests are likely given significant policy hearing. Given that non-unionism is prevalent in the US multinational sector in Ireland, AmCham expressed concerns about collectivism and unionisation. Its President submitted that AmCham members felt 'seriously threatened by the potential outcomes of this Review' (AmCham Submission, 10 April 2013). In the first 4 months, AmCham had 4 meetings with the Department (whereas ICTU/Ibec only had one each). AmCham also appears to be the only organisation to hold a direct meeting with the Minister (the others only met with department officials). Yet it is noteworthy, however, the Labour Relations Commission (LRC Submission March 2013) remarked that the MNC sector was 'largely unaffected' by the procedures. Likewise, the Industrial Development Agency, who deal with broadly the same constituency as AmCham, submitted: "IDA executives are in close and regular contact with all our clients...IDA is not aware of any particular issues from the perspective of FDI investors or employees, relating to collective bargaining, freedom of association and trade union representation (IDA Ireland Submission March
} 
process proved useful in understanding the original aims of the major stakeholders in entering the review process and how these evolved. It also enabled comparison with the final revised legislation. The second source of information is the Labour Court record on the small number of recommendations (only 4) issued under IRAA 2015 the revised procedures since their inception.

Third, and finally, the authors drew upon primary evidence via semi-structured interviews (lasting on average one hour) with six senior trade union officials from four different unions. Two of the unions participating (SIPTU and Communications Workers Union) were involved in taking $75 \%$ of cases under the revised procedures, and thus provided additional insight into how unions evaluated the legislation, its efficacy for organising and the value of the existing Labour Court rulings. Interviews also include a representative of the union Mandate in the retail sector. Mandate offered useful insights as a union engaged in several organising campaigns in recent years. In addition, the Finance Union, a smaller union historically based in banking, but expanding and organising into new sectors as membership in its traditional orbit decline due to restructuring and technological change, provided organising insights and evaluation of the revised legislation's efficacy. Shorter periodic telephone and email discussions with union officials complemented formal interviews and informed the overall picture.

\section{THE REVISED 2015 PROCEDURES}

The revised IRAA 2015 covered Irish specific matters pertinent to resolving the Supreme Court fallout, but also issues more generally characterising Anglophone bargaining rights procedures regarding thresholds of support, timelines and victimisation. Irish specific amendments included a new definition of collective bargaining, clarity on valid non-union bargaining agents and comparability criteria. We will now address whether and how the interests of the unions and the other parties were or were not met in the framing of the legislation, regarding these issues.

The 2015 legislation defined 'collective bargaining' as 'voluntary engagements or negotiations between any employer... and a trade union...or excepted body...'. The new definition of

22nd 2013)". Thus, it is not easy to explain the high level concern expressed and involvement by AmCham in the process. It may simply reflect a form of strategic pre-emption on the part of a well-resourced lobby group. 
collective bargaining includes 'voluntary engagements', an innovation moving beyond existing definitions of collective bargaining contained in prior national legislation and ILO Convention No. 154, interpreting it as confined to 'negotiations'. The legislation does not specifically elaborate or define what voluntary engagement entails. However, that voluntary engagement is succeeded by the conjunction 'or', potentially implies it has a distinct meaning from 'negotiations'. Indeed, during the review process, employer groups pushed for a definition of collective bargaining that would either include 'consultations' (Ibec Email correspondence with Department Officials 24th April 2014) or ‘voluntary engagements’ (AmCham Meeting 14th April 2014).

Non-union collective bargaining agents, or 'excepted bodies' as they are termed under the legislation, must be 'independent and not under the domination and control of an employer'. To assess non-union bargaining agents' independence, the Labour Court can consider '(a) the manner of the election of employees...(b) the frequency of elections...(c) any financing or resourcing of the excepted body...that exceeds minimum logistical support provided to it by or on behalf of the employer, and (d) the length of time the excepted body...has been in existence...' . Nevertheless, how independence is de facto realised seems ambiguous. Whatever the merits of electoral process contained in the legislation, this is only one element of independence (Butler, 2005). The provision is silent about subsequent representative capacities; for example, the ability to jointly agree on meeting agendas, time off for representative duties, or ability to ballot constituents on provisional agreements, all key features of 'independence' (cf. Batstone, 1988). It is difficult to ascertain how non-union or excepted bodies exercise full independence without a negotiation licence and access to immunities for industrial action available to independent trade unions. Employees covered by such bodies would remain under the authority of individual contractual obligations to their employer. However, the amendments do pre-empt the possibility employers might opportunistically create an excepted body in response to union organising campaigns, which international research identifies as a common strategy (Kaufman and Taras, 2016). This is less viable in Ireland because the Labour Court will consider how long the body has existed.

Overall, the revised provisions would appear to be far from satisfactory for Irish unions. FOI documents show that while AmCham and Ibec favoured maximum discretion in designing local non-union bargaining agents, ICTU sought much stricter criteria than secured in final legislation. For example, the ICTU proposed that composition of the representative structure 
be elected annually, and that the Labour Court considers the number of collective agreements the body negotiated (which would have to be in writing). Furthermore, the structure would have to provide adequate facilities and freedoms to consult members or external advisors. ICTU sought that non-union bargaining agent's register at the Labour Court, and where an application of registration be received, the ICTU would be notified and allowed 21 days to forward objections. Furthermore, non-union structures could not be registered as bargaining agents if a union could show that it had sought to engage in collective bargaining in the employment concerned during the previous five years. However, the DJEI viewed such stipulations as cumbersome and did not support their inclusion (Progress Document November 2013).

On comparability, the revised legislation asserts that the Labour Court shall not make a recommendation unless satisfied that the totality of terms and conditions provide lesser benefits to those of comparable workers employed in similar employments. Such comparisons can be based on 'workers in union or non-union employment'. The ICTU was unhappy with this blanket equivalence:

...if our purpose is to rehabilitate the 2001/2004 Acts...as distinct from pursuing a legal entitlement to union recognition, then we should not be attempt to dilute the general scheme of the legislation in how domestic comparisons should be treated.

Indeed, the comparability criteria are challenging. Taking cases in poorly organised sectors may mean that unions find it problematic to identify improvements, comparatively. Given the Labour Court tended in pre-Supreme Court judgment cases to shadow the unionised sector, the amendments imply a watering down of what unions can secure, and including non-union comparators risks diluting union gains. This might be less likely with higher-paying non-union sector comparators. Furthermore, it raises challenges in finding accurate information on pay and conditions in non-union firms, although comparators may retain a unionised focus unless countered by employers.

The revised legislation also brought Irish practice closer to Anglophone norms in introducing evidential requirements for union membership, although a strict numerical test was avoided. The Court would now decline to investigate where the number of workers involved is assessed 'insignificant' relative to the total number of workers employed by the employer in the grade, group or category to which the dispute refers. Such thresholds proved contentious during the 
review process. Both AmCham and Ibec wanted an amendment stipulating employees taking a case be representative of the entire workforce employed rather than grades or categories. ICTU countered that this 'was not acceptable' as it would prevent workers from taking cases where a dispute only related to a grade or category (ICTU Document submitted to DJEI April 2014). By avoiding precise stipulations over representativeness thresholds unions are required to meet, the amendment continues the procedures relatively relaxed approach, by comparative Anglophone standards, to membership presence. Nevertheless, while less onerous representative thresholds is advantageous insofar as 'greenfield' organising frequently relies on small numbers, what constitutes 'significant' would seem to remain open to interpretation and employer challenges.

Finally, procedural review considered timelines and victimisation measures. On timelines, extending procedural timelines would be detrimental to unions'. Unsurprisingly, employer representatives sought extensions in the review process, but were unsuccessful in securing their central demand of increasing procedural duration to 52 weeks. Victimisation measures took on pronounced significance due to the Supreme Court ruling on evidential thresholds. One potential consequence was the risk of exposing union members to employers either directly or indirectly via disclosing membership lists. Hence, from a union perspective, revised procedures required strengthening provisions to deter, halt, or penalise victimisation. The ICTU did seek a protective award restraining dismissal, and a right for unions to enter premises and meet with employees was proposed to facilitate collective bargaining (ICTU Email to DJEI Officials April 7th, 2014). Employers insisted that existing provisions in Irish law were sufficient and that victimisation for union activities was 'not a systematic issue in Irish industrial relations' (DJEI Document April 1st, 2014 pg. 7); interim relief ${ }^{2}$ and increased financial penalties were opposed. The final legislation proved favourable to unions, lessening prior fears about member exposure to victimisation, providing a stronger code of practice detailing victimisation. There is also a legislative clause (11A) enabling workers who have made a claim for unfair dismissal for union activities to apply to the Circuit Court for interim relief pending determination of claims. Statutory declaration by the chief officer of the union was deemed sufficient for determining membership presence, ruling out, for the most part, compelling members to give oral evidence at the Labour Court.

\footnotetext{
2 'Interim relief' here means that a Court can order an injunction upon an employer to desist from dismissal actions pending a full hearing of the claim.
} 


\section{UNION EXPERIENCE AND ASSESSMENT}

On balance, the revised IRAA 2015 procedures seem to offer less potential for advancing union bargaining rights compared to the post 2004 iteration. What then has been union officials' practical experiences of the revised procedures so far? Unions have taken only four Labour Court cases under the full procedural route of IRAA 2015 (see also Sheehan, 2018). There has been no return to the caseload characterising the streamlined post-2004 version of the legislation. However, despite the small pool of cases, the four rulings are themselves significant, providing an initial testing ground for unions in assessing how the reformulated procedures impact processed claims.

The first Court recommendation was noteworthy for testing provisions on non-union bargaining agents (LCR21242, Freshways Food Company and SIPTU). The employer had claimed, relying on a recent instance of a pay award, that it engaged in collective bargaining through a non-union employee representative forum. In opposition, the union argued the forum was merely for consultation, producing evidence in support from a company handbook, specifying the forum as one which '...recognised the right of employees to regular ongoing information and consultation'. The Court noted the employer provided no 'hard or reliable' documentary evidence for claiming negotiation. The Court also maintained the employer should demonstrate it was ‘customary practice’ to collectively bargain. A one-off or ad-hoc occurrence of collective bargaining, as implied by the employer's proffered example of a pay increase, was not 'practice' and therefore could not be validated as legitimate.

This case was also significant in fulfilling unions' original aspirations for the procedures as a legislative prompt pushing the employer in the direction of long-term engagement with the union locally: the union subsequently secured formal recognition and collective bargaining rights. Unsurprisingly, the union reported satisfaction with the outcome, as reported in interview:

Freshways was, ultimately, a big win. We started with 50 members, but now have 150 and have full collective bargaining rights, plus a closed shop - all as a result of using the 2015 legislation. If it fits the occasion (the legislation) forces the employer to engage with us.

(Official 1, SIPTU) 
Moreover, union officials generally regarded the case as offering reassurance that the legislation would not provide carte blanche freedoms to employers in substituting unions with non-union bargaining forums:

The definition of collective bargaining in the Act is quite positive. The Freshways case was a good starting point. I think the definition is very useful regarding non-interference and on nondomination.

(Official, Communication Workers Union).

Additionally, the attainment of 'significant' membership thresholds was not of major concern for union officials familiar with the legislation. The Court, for example, has indicated that 'significance' does not equate to a majority. In Freshways, the union claimed 63 operatives in membership (37\%) at the time of the dispute. Another dispute under the legislation (Enercon Windfarm and Technical Engineering Electrical Union) found that 69 of 147 employees (47\%) were union members. Neither employer objected to these numbers, and hearings proceeded. However, in one case (Zimmer Orthopaedics and SIPTU), 20\% density was assessed as lacking significance. What appears to be an informal Court interpretation of significance at or above approximately 30\% (in the Freshways case) is assessed favourably by union officials:

Before 2007, one member was enough, but now after Freshways you needed 30\% or thereabouts. But if you are organising you need $30 \%$ or more for it to be credible.

(Official, Communication Workers Union).

Indeed, organisers from other unions who have been attempting to expand their membership through greenfield organising in recent years felt thresholds in themselves were helpful:

The 'level' at which the threshold is set at, in fairness to the legislation, is a good one and a good place to start. More generally I am in favour of...some kind of numeric test. I think there is no problem.

(Official, Finance Union)

What has proved particularly challenging, in contrast, is comparability and associated burden of proof accompanying such tests. Unions have to ensure reliable and valid comparisons, which can now include non-union employments. This requirement has intensified workload when pursuing cases, stretching union time and financial resources. In the Conduit and Communication Workers Union disputes, four hearings over ten months were required to clarify comparability on skill, responsibility of jobs, mental and physical effort across firms 
and sectors. However, the ultimate outcome of the Conduit case, which included Court acceptance of public sector comparators with a private sector firm, was favourable to the union:

We took the 2015 route at Conduit. It took 12-18 months. We are a small union but we used a chunk of our resources. We were happy with the outcome. It vindicated our rationale in using it. It also set down precedents for the trade union movement to follow (on public sector comparisons). The employer eventually went beyond the terms of the Court's Conduit recommendation in respect of pay - and some other terms and conditions. But the employer will not recognise us. If you did a brutal accountancy exercise you would be a long time getting a 'profit'. In terms of an investment for the members in that case, i.e. in their terms and conditions, it was worth the risk. Sometimes unions have to step up and do that type of thing.

(Official, Communication Workers Union)

In the Enercon dispute, three hearings over five months were necessitated, accompanied by six rounds of union submissions in writing to the Court over nine months to demonstrate validity of the union's industry comparators. The employer repeatedly challenged these. Disputed comparisons incorporated such items as the composition of work groups, relative skill mix, and working patterns in associated companies. The Court eventually decided it could not proceed to hear the case given perceived lack of information to enable comparative understanding of one set of workers' jobs compared to another.

The effect of these two cases, in particular the burden of proof around comparators and case duration, is inhibiting the procedures appeal to unions. All union officials interviewed regarded this as weakening local organising possibilities. This was especially so in sectors like retail, hotels and banking, where unions experienced particular difficulties in identifying comparators:

The comparator criteria waters down the legislation. There is no problem finding any comparators in pharma, chemicals and so forth, areas with plenty of members, high unionisation. But unions have a big problem organising in retail and hotels. The legislation is of limited value in this area.

(Official 2, SIPTU)

If you look at the retail sector, most non-union employers pay higher than union rates of pay. Non-union Aldi and Ikea pay the living wage, which is higher than unionised Tesco. A lot of non-union employers are paying at least as much if not more than traditional unionised employers. We have no comparators because they are not out of line.

(Official, Mandate)

If you take the one non-union retail bank which we are organising in currently, KPC, while their terms of employment are slightly more flexible and conditions of employment are possibly slightly worse than the established banks, I don't believe they are not so sufficiently bad that the Act would do anything for us or provide anything. Essentially this comparator element says you can only really go after the bottom feeder, you have to target the worst employer and go after them. 


\section{ALTERNATIVE UNION STRATEGIES}

The IRAA 2015 has not been used as often as the 2004 iteration. If the procedures are of less interest to unions than hitherto, what alternatives are being adopted or considered? Currently, unions report a preference for processing disputes in non-union firms under the older aforementioned Industrial Relations Act 1969; known in the union movement as the 'traditional route' to union recognition. This is essentially where a recognition dispute plays out, depending on the balance of power locally; albeit buoyed by the moral support (where forthcoming) of favourable Labour Court recommendations. In broadly the same period as IRAA 2015 (20152019), the Labour Court has issued 25 recommendations on union recognition under Section 20 of the IRA 1969. Unions tend to favour this process because it is quicker, far less legalistic in terms of burden of proof, and the Labour Court nearly always provides voluntary recommendations favouring recognition (it is not compulsory for employers to comply). Union officials emphasised that this traditional IR route is currently their first option for pursuing recognition, rather than the more legalistic IRAA 2015 (which in any case cannot propose recognition):

There seems to have been an upsurge in those types of recognition cases using the Industrial Relations Act 1969, which proves that unions don't seem to have any faith in the 2015 Act.

(Official, Mandate)

From our perspective, the 2015 Act is a secondary piece of legislation...In our judgement, if we go the traditional route (Industrial Relations Act 1969) and we are organised well enough to be ready to have a dispute - then this is our first option ...

(Official 1, SIPTU)

You would have expected there to have been more cases by now for the Industrial Relations Act 2015... But because of the legal profession we (union) look more carefully. Employers just farm these cases out to lawyers and spend a lot of resources to stop cases at preliminary stage.

(Official 2, SIPTU)

However, unions know that the IRA 1969 route is not a tenable long-term solution given that it does not circumvent the problems of voluntarism. At best its use may reflect optimism among some union officials that the post-crisis economic recovery since 2015 might provide something of a 'sellers' market' and boost their bargaining power. At present then, two alternative strategies are reported as in embryonic stages of development; both focused on securing mandatory legal rights to collective bargaining (one has a domestic Irish focus, whereas the other locates potential salvation at European level). 
The first revisits the question of union recognition and/or a mandatory right to collective bargaining at a national-level. The preferred option reported among mainly smaller private sector unions like Mandate and FSU is to campaign for a referendum on a Constitutional amendment, followed by national legislation (on union recognition/collective bargaining rights) if this passed. They also see potential in a referendum campaign for increasing visibility of the labour movement, and serving as an organising pivot.

It would look like a constitutional amendment or change would be needed to achieve union recognition. That would be a big challenge, but I think it is something the union movement should embrace and campaign for. And the campaign should be about mobilising or organising workers... The campaign to try to win it is as important as winning it, so there is no loss putting out a clear policy position and demand for a constitutional amendment, the right to organise, the right to recognition, the right to collective bargaining etc.

(Official, Finance Union)

Internally, the ICTU is less amenable to such a campaign, believing the chances of a referendum victory are uncertain, with all the repercussions such a defeat could bring in terms of wider legitimacy. Rather, the ICTU (2019) favours a campaign for greater statutory protection for union members through enactment of a Trade Union Rights Act, which would chiefly prioritise rights of union access to workplaces. Second, the ICTU and larger affiliated unions are contemplating European level legal solutions. ICTU's 'Route to Reform’ states that, working with the European Trade Union Congress (ETUC), it will campaign for an EU Directive on harmonising collective bargaining to establish a 'right to bargain' in Irish law. Some prominent industrial relations practitioners see value in this approach; notably a former Labour Court chair who had a substantial influence on the original 'right to bargain' legislation (Duffy, 2019). The position here is that the EU could harmonise collective bargaining rights across Europe through an EU Directive:

It could address concerns around the impact that any legislative initiative would have on foreign direct investment as the same rules would apply throughout the European Union. If a solution were to be found in a European Directive, the doctrine of supremacy of EU law would overcome any lingering doubt around the Constitutionality of any legislative initiative in this sphere.

(Duffy, 2019)

A component of this is that unions would seek to extend legally binding coverage of multiemployer sectoral collective bargaining; ostensibly along similar lines to sectoral bargaining models in northern European countries. Under IRAA 2015 (Part II), Ireland already has legally binding Sectoral Employment Orders (SEO) in the construction, mechanical craft and electrical 
contractor sectors, setting and extending minimum pay and conditions across these sectors. Some officials view such SEO's as a useful organising tool:

(SEO's are) a far better mechanism ... you can organise entire industries, grades sectors (although) there is a huge resource issue ... (Official 1, SIPTU).

In part, unions recognise extending SEOs to all sectors is difficult, however, because not only is employer support for such endeavours often lacking, but also there are no viable coordinating institutions in several sectors for this type of bargaining to occur, particularly on the employer side. For some unionists, sectoral bargaining would also have to build on and not supplant workplace bargaining and organising:

I am only in favour of sectoral bargaining on the basis of having a right to access workplaces, right to organise and collective bargaining. Otherwise it becomes extremely damaging. You may well achieve standardised working conditions but your union density will decline underneath you if you haven't got a presence at workplace level.... However, if we did achieve the right to access and all those things at workplace level then sectoral agreements do have a value. I think it is important that it only happens after you achieve workplace strength (Official, Finance Union).

Overall, trade union officials interviewed evidently had mixed views on whether to pursue domestic or European avenues (or a combination) to strengthen statutory collective bargaining rights. Irish unions have not coalesced around a unified strategic position.

\section{DISCUSSION}

This article has assessed Ireland's revised Industrial Relations (Amendment) Act, 2015, governing union representation rights for union members in non-union firms. The research is supported by primary empirical data from union officials, so it offers a valuable contribution to this important IR topic. We outlined how comparative Anglophone countries have opted to address contested questions of union recognition via statutory procedural supports. While there is variation across countries, many such mechanisms have limitations regarding what they can offer unions seeking to secure bargaining rights. There are well-established pitfalls in securing supporting thresholds, timelines for completion and employer interference. In contrast, our comparative assessment of Ireland illustrates an alternative route to bargaining rights, primarily path dependent upon its Constitution and, latterly, the desire not to alienate non-union American multinationals. 
Instead, Ireland has a dispute resolution procedure allowing unions to represent members and apply to access third party institutions to resolve conflicts over pay and conditions where collective bargaining is not present. The intention was to secure outcomes shadowing collective bargaining norms in comparable organisations - a form of indirect 'arms-length bargaining' (Geary and Gamwell, 2019). However, the procedures were subject to employer challenge culminating in the 2007 Supreme Court 'Ryanair judgment', and subsequently exposed to a less than complimentary interaction between common law norms of the judiciary and the openended pragmatism preferred by many industrial relations practitioners for conflict resolution. As our analysis and empirical data indicate, the reforms encapsulated in IRAA 2015 have not surmounted these issues. The intrusion of the civil courts into the procedural dynamic has compelled a traditional industrial relations process of collective dispute resolution (and the Labour Court, a traditional IR court) to become increasingly legalistic (Teague, 2009). With the Labour Court now adjudicating upon legal principles inherent in the determination of legal rights and responsibilities, the participation of lawyers and judicial reviews is more common. As such, it appears highly doubtful that IRAA 2015 provides an adequate or stable solution to advancing bargaining rights for unions.

The procedural requirements for comparability, in particular, weaken the substantive value of the legislation for unions by substantially raising the burden of evidence required from them. While more stringent evidential requirements are conducive to creating due process and procedural legitimacy, the trade-off can be procedural inefficiency. Inefficiency is a bête noire of effective conflictual resolution mechanisms in industrial relations (Budd and Colvin, 2014: 14). Furthermore, comparability, in principle, dilutes the so-called 'right to bargain'; it is now a conditional right. It matters little what the issues in dispute are for individual workers. If the Court cannot determine benchmark pay and conditions with external practices elsewhere, there is a denial of employee voice, resulting in democratic disenfranchisement and restricted access to workplace representation and bargaining rights. Of course, some might counter that it is reasonable for the Court to rely on some benchmark in sorting cases, and one could reasonably argue this is the price of access to the powers of the Act. However, it is a blunt instrument and does not do justice to within sector heterogeneity, limiting workers' ability to capitalise on the successes of higher than average performing firms within an industry insofar as each disputed set of terms and conditions is assessed at an 'in line' average. Thus, the form of comparability adopted arguably diminishes the legislation relative to the practices of statutory rights prevalent in other Anglophone countries. Unions, like Ireland's biggest (general) union SIPTU, might 
pragmatically retain usage of the Act as a secondary part of their armoury, selectively pursuing a small number of cases in workplaces where they feel the balance of advantage on various test items is favourable. At the time of writing, for example, SIPTU is pursuing a new case under IRAA 2015 in the stevedoring sector.

Given the perceived limitations of IRAA 2015 for revitalising unions, two new alternative options (domestic and European-level) are under consideration by the Irish union movement. Nevertheless, these approaches present their own challenges. A union-based lobbying approach for 'institutional security’ (Clegg, 1976) provides a less risky source of political influence than relying on voluntarily mobilising and organising members at local-level to build critical mass (Heery and Adler 2004; McAlevey 2016). While Irish unions have devoted increased attention to organising campaigns (with variable results), even advocates identify challenges like employer hostility and finite resources (Geary and Gamwell, 2019; Murphy, 2016, Murphy and Turner, 2014). Yet the institutional reforms secured via a statutory recognition mechanism or mandatory right to workplace collective bargaining are no panacea. Assuming a union campaign to secure statutory recognition and mandatory collective bargaining rights at locallevel along existing Anglophone lines is successful, it would likely only operate at the margins, much like it currently functions elsewhere. That is, it might make some individual cases relatively more straightforward for unions to secure recognition. Nevertheless, as is the case in other Anglophone places, it would be unlikely, of itself, to stem the decline in collective bargaining coverage or union density. For example, in the UK, which approximates most closely to Ireland in the Anglophone sphere, the period since the introduction of statutory recognition in 1998 has seen membership and collective bargaining coverage erode (Vandaele, 2019). That union density and collective bargaining coverage are declining in other Anglophone countries imply that statutory recognition/collective bargaining rights are insufficient in isolation and may offer limited dividends for Irish unions. Even the argument that a statutory regime would make it easier to pursue recognition dispute claims cannot be guaranteed given the likely compromises in procedural design employers would demand (as occurred with IRAA 2015). There appear to be constraints on what unions in Ireland and elsewhere can achieve by almost exclusively focusing on workplace-level representational models (Ibsen and Tapia, 2017). That said, some union officials observe that legislation providing a mandatory right to collective bargaining is a start in Ireland, and better than what they have now with IRAA 2015. 
What of 'regulatory' models of sectoral level collective bargaining, which would move Ireland towards multi-employer bargaining found in Northern European countries? In Ireland, ICTU calls for multi-level rights to collective bargaining appear to reflect the need to create a wider frontier on union revitalisation (Bogg, 2012; Ewing and Hendy, 2017; Forsyth et al. 2017; Ibsen and Tapia, 2017). Any attempts to strengthen representation by extending sectoral bargaining coverage along the lines of some other EU countries would need to address the widespread problem of freeriding and the weakening of incentives to join unions associated with this. Means to counter such problems are debated around Europe, e.g. paying bonuses only to union members or permitting them to take extended holidays (Hoffmann, 2019) or turning union membership into a 'default option' where unions already have members or a collective agreement in the UK context (Harcourt et al. 2019). Such proposals remain at the level of speculative debate, however.

To conclude, despite the endeavours of policy reformers some twenty years ago to circumvent the long-standing historical constitutional impediment of trade union recognition in Ireland, and recent attempts to resuscitate those procedures after the 2007 Supreme Court judgment, union representation, recognition and collective bargaining rights remain a contested and unresolved conundrum in Irish industrial relations. Problematically, Irish unions, like elsewhere in the Anglophone world, face a complex and formidable big picture structural combination of institutional, legal, labour market, demographic, and political economy challenges. Isolated institutional tinkering of bargaining procedures alone cannot resolve such fundamental challenges, especially without much stronger support for IR pluralism from the state. This co-exists with uncertainty within the Irish labour movement about alternative options and strategic choices regarding union revitalisation and renewal.

\section{References}

Barry, M., \& Walsh, P. (2007). State Intervention and Trade Unions in New Zealand. Labor Studies Journal, 31(4): 55-78.

Bogg, A. (2012) 'The death of statutory recognition in the United Kingdom', Journal of Industrial Relations, 54(3): 409-425.

Bogg, A. and Novitz, T. (2018) 'The Politics and Law of Trade Union Recognition: Democracy, Human Rights and Pragmatism in the New Zealand and British Context', Victoria University of Wellington Law Review.

Budd, J. and Colvin, A.J.S. (2014). 'The goals and assumptions of conflict management in organizations', in W.K. Roche, P. Teague and A.J.S. Colvin (eds.), The Oxford Handbook of Conflict Management in Organizations. Oxford: Oxford University Press. 
Clegg, H. (1976). Trade unionism under collective bargaining: a theory based on comparisons of six countries. Oxford: Blackwell.

Cullinane, N. and Dobbins, T. (2014) 'Considering the impact of the right to bargain legislation in Ireland: review’, Industrial Law Journal, 43(1): 52-83.

Cullinane, N. and Dundon, T. (2012), 'Unitarism and employer resistance to trade unionism', International Journal of Human Resource Management, 25(18): 2573-2590.

D’Art, D. and Turner, T. (2011) 'Irish trade unions under social partnership: A Faustian bargain?', Industrial Relations Journal, 42(2): 157-173.

Doherty, M. (2011) 'It must have been love...but it's over now: The crisis and collapse of Irish social partnership’, Transfer: European Review of Labour Research, 17(3): 371-385.

Doherty, M. (2013) 'When you ain’t got nothin', you got nothin' to lose...Union recognition laws, voluntarism and the Anglo Model', Industrial Law Journal, 42(4): 369-397.

Duffy, K. (2019), ‘The Elusive 'Right to Bargain’ Is it Attainable and What Does it Mean?', Paper presented at IRN conference 2019, Industrial Relations News, 18. Dublin: IRN Publishing.

Ewing, K.D. (2005) 'The function of trade unions', Industrial Law Journal, 34(1): 1-22.

Ewing, K.D. and Hendy, J. (2017) 'New perspectives on collective labour law: trade union recognition and collective bargaining', Industrial Law Journal, 46(1): 23-51.

Forsyth, A., Howe, J., Gahan, P. and Landau, I, (2017) 'Establishing the right to bargain collectively in Australia and the UK: Are majority support determinations under Australia's Fair Work Act a more effective form of union recognition?', Industrial Law Journal, 46(3): 335-365.

Gall, G. (2010). Statutory Union Recognition Provisions as Stimulants to Employer Anti-Unionism in Three Anglo-Saxon Countries. Economic and Industrial Democracy, 31(1), 7-33.

Gall, G. (2012) ‘Union recognition in Britain: the end of legally induced voluntarism?’, Industrial Law Journal, 41(4): 407-438.

Geary, J. and Gamwell, S. (2019). 'An American solution to an Irish problem: a consideration of the material conditions that shape the architecture of union organizing'. Work, Employment and Society, 33(2), 191-207.

Gibbons, T. (2015) 'The Industrial Relations (Amendment) Act 2001: A useful organising tool for Irish trade unions or last refuge of the powerless?', Industrial Law Journal, 44(3): 472-477.

Godard, J. (2003) 'Do labor laws matter? The density decline and convergence thesis revisited', Industrial Relations, 42, 458.

Gunnigle, P., Lavelle, J, and McDonnell, A. (2009) 'Subtle but deadly? Union avoidance through “double breasting” among multinational companies', Advances in Industrial \& Labor Relations, 16: 51-74.

Harcourt, M., Gall, G., Kumar, R.V. and Croucher, R. (2019) 'A Union Default: A Policy to Raise Union Membership, Promote the Freedom to Associate, Protect the Freedom not to Associate and Progress Union Representation', Industrial Law Journal, 48(1): 66-97.

Heery E. and Adler L. (2004). 'Organizing the unorganized', in Frege C. and Kelly J. (eds.) Union revitalization in a globalizing economy. Oxford: Oxford University Press, 45-69. 
Hoffmann, R. (2019). 'Bonus for union members', Online at: https://www.deutschlandfunk.de/dgbchef-hoffmann-bonus-fuer-gewerkschaftsmitglieder.694.de.html?dram:article_id=447515

Hogan, G. W. and Whyte, G. (2003). The Irish Constitution. LexisNexis/Butterworths.

Holgate, J. Simms, M. Tapia, M. (2018) 'The limitations of the theory and practice of mobilization in trade union organizing’. Economic and Industrial Democracy, Online Early.

Ibsen, C. L., and Tapia, M. (2017). Trade union revitalisation: Where are we now? Where to next?. Journal of Industrial Relations, 59(2), 170-191.

Irish Congress of Trade Unions (2019) Route to Reform. Dublin.

Kaufman, B. E., and Taras, D. G. (2016). Nonunion employee representation: history, contemporary practice and policy. Routledge.

McAlevey J.F. (2016). No Shortcuts. Organizing for power in the new gilded age. Oxford: Oxford University Press.

Murphy, C. (2016). Fear and leadership in union organizing campaigns: An examination of workplace activist behavior. SAGE Open, 6(1), 2158244015623932.

Murphy, C. and Turner, T. (2014) 'Organising non-standard workers: union recruitment in the Irish care sector’. Industrial Relations Journal, 45(5): 373-388.

O' Sullivan, M. and Gunnigle, P. (2009) 'Bearing all the hallmarks of oppression: union avoidance in Europe’s largest low-cost airline’, Labor Studies Journal, 34(2): 252-270.

Sheehan, B. (2008) 'Employers and the traditional industrial relations system: how the bonds have been loosened', in T. Hastings, (ed.), The State of the Unions: Challenges facing Organised Labour in Ireland, Dublin: Liffey Press.

Sheehan, B. (2018) ‘Clear lessons emerge from recent 'right to bargain' Labour Court cases', Industrial Relations News, 28. Dublin: IRN Publishing.

Teague, P. (2009) 'Path Dependency and Comparative Industrial Relations: The Case of Conflict Resolution Systems in Ireland and Sweden', British Journal of Industrial Relations, 47(3): 499-520.

Turner, T., D'Art, D. and O’Sullivan, M. (2013) Are Trade Unions Still Relevant? Union Recognition 100 Years On, Dublin: Orpen Press.

Vandaele, K. (2019) Bleak prospects: mapping trade union membership in Europe since 2000. Brussels: ETUI.

Walpole, K. (2015). 'The Fair Work Act: Encouraging collective agreement-making but leaving collective bargaining to choice'. Labour \& Industry, 25(3), 205-218.

Walsh, F. (2018). 'Trade Union density in Ireland since 2003: what do the statistics tell us?' Industrial Relations News, 27. Dublin: IRN Publishing.

Wood, S. and Godard, J. (1999) 'The statutory union recognition procedure in the employment relations bill: a comparative analysis’, British Journal of Industrial Relations, 37(2): 203-245. 